\title{
NUTRITION IN THE REPRODUCTION OF FARM ANIMALS
}

\section{J. J. ROBINSON}

Rowett Research Institute, Greenburn Road, Bucksburn, Aberdeen AB2 9SB

\section{CONTENTS}

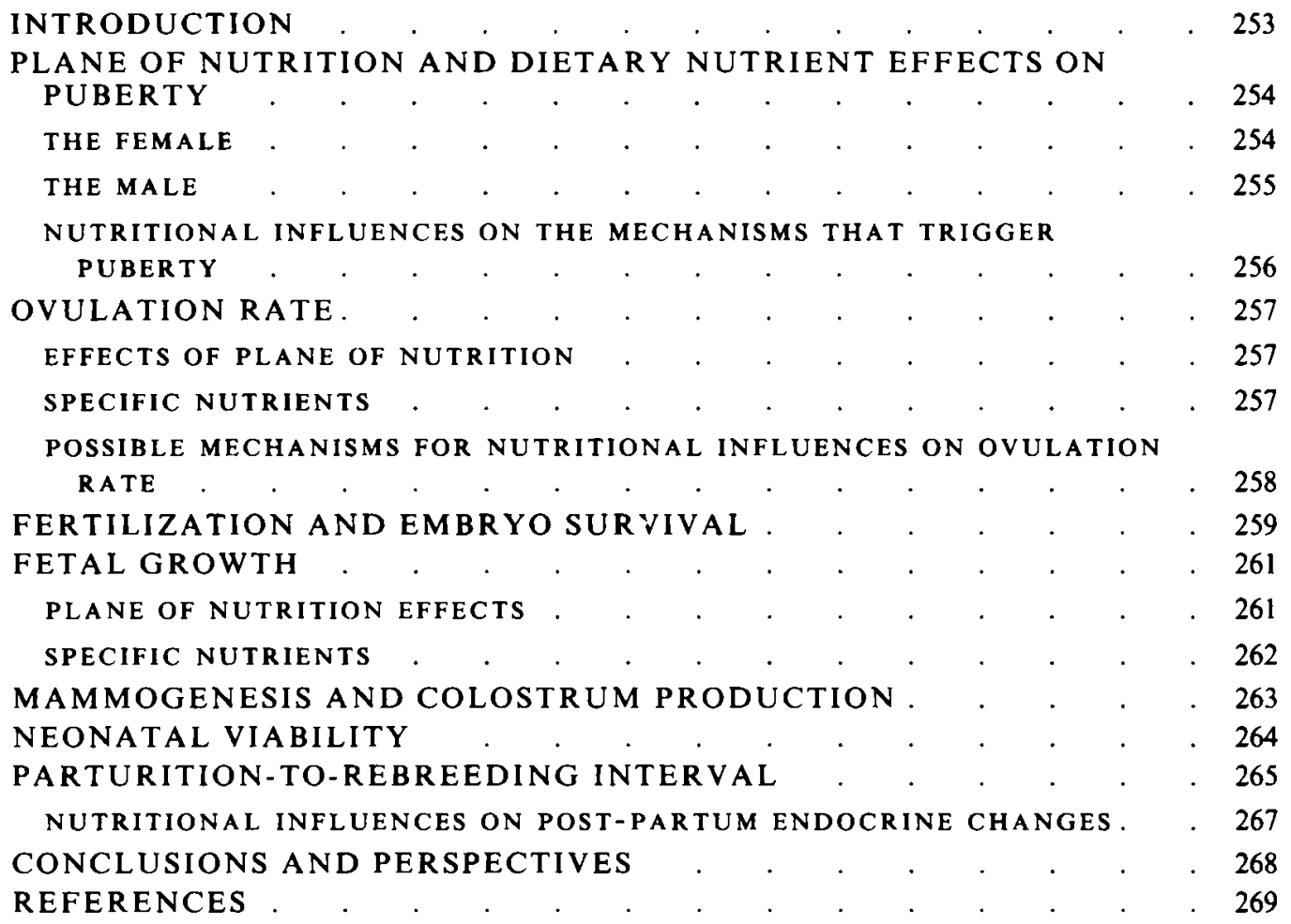

\section{INTRODUCTION}

There is still uncertainty about the earliest stage of development at which nutrition influences an animal's subsequent ability to achieve its genetic potential for reproduction. Prenatal growth retardation caused by feeding ewes on a ration as low as 0.5 times maintenance during early pregnancy had no subsequent detrimental effect on either the natural or gonadotrophin-stimulated ovulation rate of the progeny, leading Parr et al. (1986) to conclude that the embryonic development of the primordial germ cells in the ovary was not permanently affected by undernutrition. Martin \& Crenshaw (1989) cite literature which suggests that low-plane feeding during the period of oogenesis in the pig ( $40 \mathrm{~d}$ post mating to $35 \mathrm{~d}$ post partum) may suppress subsequent ovulation rate. Although there is some evidence in their own experimental observations that this is so there are opposing nutritional influences on embryo survival leading to no significant effect on litter 
size. In sheep, moderate undernutrition during the late prenatal (6 weeks) and early postnatal growing phases caused a significant depression in adult ovulation rates. This observation and others on the reproductive performance of sheep prompted Gunn (1983) to suggest that provided nutrition is adequate during the prenatal period and for the first 8 weeks of post-natal life, the genetic potential for ovulation and lamb production is unlikely to be impaired. On the other hand, Williams (1984) observed that undernutrition for an 8-week period from 6 weeks of age reduced ovulation rates in ewes for up to 3 years. In contrast to this uncertainty and the need for more long-term studies, there are many well-defined medium- and short-term effects of nutrition on the expression of an animal's reproductive potential. The present review includes a discussion of nutritional effects on puberty, ovulation rate, embryo survival, fetal growth, mammary development, colostrum production, perinatal survival, lactation and the parturition to rebreeding interval. Quantitative analyses of these effects are set out together with the results of recent investigations which probe the underlying mechanisms involved in the nutritional modulation of these processes.

\section{PLANE OF NUTRITION AND DIETARY NUTRIENT EFFECTS ON PUBERTY}

\section{THE FEMALE}

Low-plane feeding that reduces growth rates during the rearing phase to $50 \%$ of the animal's potential delays puberty in cattle (Day et al. 1986), red deer (Cervus elaphus; Adam \& Moir, 1985), sheep (Dýrmundsson, 1987), goats (Doney et al. 1982) and pigs (Aherne \& Kirkwood, 1985; Dyck, 1988); the effects are more pronounced when applied in the early post-natal than immediate prepubertal phase. With less severe nutritional regimens the effects vary but in some instances are still important quantitatively. For example, Van Lunen \& Aherne (1987) observed that the relatively modest reduction in the feed intake of modern pig genotypes to $85 \%$ of ad lib. from $27 \mathrm{~kg}$ live weight delayed puberty by $26 \mathrm{~d}$. In practice the range of feeding levels adopted during the rearing period in current pig production systems is unlikely to alter puberty in the gilt by more than a few weeks and the same is true for modern temperate-region systems of beef (Ferrell, 1982) and dairy cattle (Petitclerc et al. 1983) production. In contrast it is not unusual for the low planes of nutrition of heifers reared on the semi-arid grasslands of the tropics to delay puberty by 9 months (Topps, 1977). Even under temperature conditions, the failure of hill and upland grazings to promote the growth rates needed to achieve puberty within the restricted breeding season exhibited by red deer, sheep and goats can delay puberty in these species for an entire year (red deer: Adam \& Moir, 1985; Loudon, 1987; sheep: Dýrmundsson, 1987). Less severe feed restrictions allow puberty to occur within the first breeding season but at a lighter weight and older age than for those on a high plane of nutrition (Foster et al. 1985). These and other seasonal influences, such as the 2-month advance of puberty in Friesian heifers born and reared under increasing rather than decreasing daylengths (Roy et al. 1980), provide a wide within-species range in the pubertal body size of ruminants (Hansen, 1985) with no evidence that the fatness or protein content of the body are important indicators of sexual maturity (sheep: Moore et al. 1985; cattle: Brooks et al. 1985). In pigs the evidence for a threshold in body composition for the attainment of puberty is equivocal. Den Hartog \& Noordewier (1984) found a positive relationship between backfat thickness and age at puberty of gilts on a high plane of nutrition but not for those on a low plane of nutrition during the rearing phase, suggesting a threshold fatness for the attainment of puberty in young fast-growing animals. In 
contrast, King (1989a) observed that high levels of body fat at a young age tended to delay puberty; precocious puberty in his experiment occurred in those animals that were heavier and leaner.

From a review of early studies on laboratory rats, Kirkwood et al. (1987 b) suggested that the varying effects of plane of nutrition on puberty could be explained by betweenexperiment differences in protein intake and the same may be true in farm animals. Thus, for gilts a dietary protein content of $160 \mathrm{~g} / \mathrm{kg}$ comprising the correct balance of amino acids, in particular lysine (King, 1989 b), will ensure that puberty is not delayed by insufficient protein unless total feed intake is unacceptably low (Britt et al. 1988). Recent studies suggest that supplementing the diet with tyrosine, a precursor of the brain neurotransmitters, dopamine and noradrenaline, may also advance puberty in the gilt (for review, see Kirkwood et al. $1987 \mathrm{~b}$ ). In ruminants, the low protein content of tropical pastures $(\leqslant 80 \mathrm{~g} / \mathrm{kg}$ ) delays puberty (Oyedipe et al. 1982) by reducing the production of the animal's major source of amino acids, i.e. microbial protein, to levels that not only restrict growth (Topps, 1977) but often fail to meet maintenance needs. Likewise for many of the minerals and vitamins, the lack of information on their specific roles in the neuro-endocrine mechanisms that initiate puberty has led to the assumption that they influence the attainment of puberty through their general effects on growth. Recently Hurley \& Doane (1989), making a plea for greater research effort into identification of the specific roles of the vitamins and minerals in reproductive tissues, suggest a number of areas worthy of study. For puberty in the female these could involve the possible role of the ovarian and pituitary cellular retinol-binding proteins in determining the mode of action of vitamin A, and, from the recent study of Phillippo et al. (1987), further investigations on whether or not the molybdenum-induced interference in luteinizing hormone (LH) secretion that delays puberty in heifers is caused by a disruption in ovarian steroid secretion.

\section{THE MALE}

The inter-relationships between nutrition, growth rate and age at puberty in the male are very similar to those in the female. Thus, males reared on high as opposed to low planes of nutrition reach puberty at earlier ages and heavier body-weights (Waddad \& Gaili, 1985). In common with the female, nutritional influences are much more pronounced if they occur in early life rather than post weaning (Pruitt et al. 1986). Feed restriction of Merino ram lambs prevented them attaining puberty in their first potential breeding season (Ketut Sutama \& Edey, 1985). More liberal subsequent feeding allowed puberty to occur the following year with those growing at $130 \mathrm{~g} / \mathrm{d}$ during the re-alimentation period reaching puberty 4 weeks earlier and sustaining higher sperm densities $\left(2.5\right.$ v. $\left.2.1 \times 10^{9} / \mathrm{ml}\right)$ than those growing at $80 \mathrm{~g} / \mathrm{d}$. Similar reductions in sperm concentrations leading to overall reductions in sperm production have been noted by Alkass et al. (1982) following feed restriction of rams to $75 \%$ of their estimated maintenance needs for periods in excess of the 5-6 weeks required to develop sperm from the spherical spermatids in the germinal epithelium to fully mature spermatozoa in the distal cauda epididymidis (Amann, 1987). High-plane feeding of boars leading to leg weakness and lack of libido prompted the recommendation of lower planes of nutrition for boars in Dutch artificial insemination centres, but recently Kemp et al. (1989) showed that maintenance feeding regimens, without a feed increment for the energy cost on the day of mating (1.3 MJ metabolizable energy (ME)), reduced spermatozoa numbers, but not their quality, by 32 and $41 \%$ compared with those receiving twice and thrice maintenance rations. With regard to specific nutrients, low concentrations of protein (about $80 \mathrm{~g} / \mathrm{kg}$ ) occur widely in ruminant feeds and compared with diets containing $145 \mathrm{~g} / \mathrm{kg}$ have been shown to delay puberty in indigenous Nigerian 
bulls and their Friesian crosses. Interestingly the extent of the delay was much greater ( 5 months) for the crossbreds (Rekwot et al. 1987). For the minerals and vitamins the high zinc content of semen and the importance of this element in spermatogenesis coupled with its synergic role in the uptake by the spermatozoa of vitamin A is noteworthy, particularly as vitamin $\mathrm{A}$ itself plays an essential role in the attainment of puberty and in the maintenance of both libido and the integrity of the testicular germinal epithelium (Hurley \& Doane, 1989).

\section{NUTRITIONAL INFLUENCES ON THE MECHANISMS THAT TRIGGER PUBERTY}

There is general agreement that plane-of-nutrition-induced restrictions in the onset of puberty in animals that have achieved their threshold age for the attainment of puberty (Prunier et al. 1987) are caused by an inhibition in the pulsatile release of gonadotrophinreleasing hormone (GnRH) from the hypothalamus and consequently of LH from the pituitary (Foster \& Olster, 1985, sheep; Day et al. 1986, cattle; Kinder et al. 1987, sheep and cattle; Britt et al. 1988, pigs). This inhibition of the GnRH pulse generator occurs in the presence of ample supplies of both hypothalamic GnRH and the pituitary gonadotrophins. In testing the sensitivity of the neuronal mechanisms controlling LH secretion to changes in nutrition, Foster et al. (1988) have found the ovariectomized ewe lamb, which is free from the well recognized ovarian steroidal and non-steroidal feedback regulation of LH secretion (Findlay \& Clarke, 1987) a particularly useful model. In their studies the suppression of LH secretion (Foster et al. 1988) and follicle-stimulating hormone (FSH; Padmanabhan et al. 1989) in undernourished lambs was reversed by highplane feeding, the reversal occurring in some individuals within $2 \mathrm{~d}$ of changing their feeding level. Similarly parenteral infusion of a dextrose-amino acid mixture was as effective as high-plane feeding in sustaining LH pulse frequency. This experimental model illustrates that the mechanisms controlling the GnRH neuron are extremely sensitive to changes in the nutritional state of the animal. It thus provides a powerful means of identifying which specific nutrients mediate plane of nutrition effects on puberty. At present these remain speculative. Steiner (1987) and Foster et al. (1988) argue that for energyyielding nutrients insulin may play an important role in that it binds to receptors in those regions of the brain (arcuate nucleus and median eminence) which are thought to be involved in the control of GnRH secretion. For protein per se it may be via the action of specific amino acids that are needed for the synthesis of the GnRH neurotransmitters (Foster et al. 1988), but confirmation of this will require more research into the nature of the neurotransmitter systems that control the secretion of the pituitary hormones (Dailey et al. 1987). Although the ovariectomized ewe lamb is undoubtedly useful in clarifying the mechanisms linking nutritional status and gonadotrophin secretion, in practice the true nature and timing of these mechanisms are regulated by ovarian feedback (Wolfe et al. 1989). In this regard Bronson \& Manning (1988) postulated from their studies on rats that the detrimental effects of food restriction on puberty influenced GnRH secretion in two ways, i.e. a rapid alteration in secretion caused by food intake itself but not involving gonadal feedback mechanisms, and a long-term influence involving the growth and development of the body and evoking alterations in the sensitivity of GnRH secretion to the gonadal steroids. 


\section{OVULATION RATE}

\section{EFFECTS OF PLANE OF NUTRITION}

The variations in nutrient intake that occur in practical farming systems have major effects on the ovulation rate of sheep and goats (Doney et al. 1982; Henniawati \& Fletcher, 1986), moderate effects in the pig (Aherne \& Kirkwood, 1985), with very minor or no effects in the rabbit (Partridge, 1989). For sheep, long-term plane of nutrition effects are reflected in body condition and it is not unusual for ewes on temperate hill grazings or in the arid tropics and sub-tropics to have less than $10 \%$ fat in their fleece-free empty body and average ovulations $<1$. In contrast, high-plane feeding leading to $25 \%$ fat in the body doubles ovulation rate. For prolific low-ground breeds the effects of body condition on ovulation rate are equally dramatic, with those at the lower and upper end of the recommended body condition scale ( 20 and $30 \%$ fat respectively) having mean ovulations of 2.3 and 3.4 (Rhind et al. 1986). Short-term plane of nutrition (flushing) effects appear to occur only within a specific intermediate range of body condition (Gunn, 1983) and average $0 \cdot 2-0 \cdot 4$ ovulations (Rhind et al. 1989 b) .

In the sheep the major long-term nutritional influences on ovulation rate are seen in the adult rather than at the pubertal oestrus (Quirke \& Gosling, 1979; Hamra \& Bryant, 1982), but the opposite is true in pigs. For example, in the major European pig breeds daily ME intakes of $34 \mathrm{MJ}$ as opposed to $21 \mathrm{MJ}$ during the rearing phase enhanced average ovulation rate by 1.5 with a further response of 1.8 when intake during the oestrous cycle was increased to $41 \mathrm{MJ}$ (for review, see Aherne \& Kirkwood, 1985). Following the birth of the first litter, however, large differences in feeding levels during lactation, leading to differences in body-weight of 25 (Baidoo \& Aherne, 1988) and $36 \mathrm{~kg}$ (King \& Dunkin, $1986 a$ ) had no effects on subsequent ovulation rates. Indeed evidence for an effect of highplane feeding between weaning and remating (flushing) on ovulation rate was also absent (Baidoo \& Aherne, 1988). Yet in gilts, 'flushing' regimens applied during the follicular phase invariably increase the number of ovulations (Cox et al. 1987; Flowers et al. 1989), albeit from a lower base line.

\section{SPECIFIC NUTRIENTS}

In pig nutrition, quantitative information on the effects of feeding level on ovulation rate are now being augmented with studies on the effects of altering dietary protein levels (King \& Dunkin, 1986b), lysine concentrations (Grandhi, 1988; King, 1989b) or fat inclusion rates (Grandhi, 1988), but so far none of these has enhanced ovulation rates above those for conventional diet formulations. With sheep, observations made during the 1970 s on grazing ewe flocks in Western Australia showed that in certain circumstances the provision of high-protein supplements in the form of lupin grain could enhance ovulation rate. The nature of these responses has been thoroughly reviewed by Smith $(1985,1988)$ and the findings interpreted against the background of his own experiments involving a range of protein and energy intakes. Briefly, the specific protein response is short-term, exercising its effect in the $12-d$ period preceding ovulation. When it occurs, its magnitude $(0 \cdot 2-0 \cdot 4$ ovulations) is similar to that seen in conventional 'flushing' regimens involving short-term increases in feed intake, but the extent of its modification by ewe breed and body condition or by level of energy intake is unclear.

Although the responses in ovulation to lupin grain prompted the initial studies on the specific effects of protein there is still debate about whether or not the lupin-grain response is a true protein one. Having obtained similar average increases of about 0.4 ovulations in Merino ewes that received the same amounts of supplementary rumen-undegradable 
protein (UDP) from either lupin grain or formaldehyde-treated casein and no increase in those given a purely energy source of wheat starch, Nottle et al. (1988) argue that the lupininduced ovulatory response is the result of a significant increase in the supply of UDP. More recently Teleni et al. (1989) also used Merino ewes and reported average increases in ovulation rate of $0.33,0.35$ and 0.32 for those receiving lupin grain, intravenous infusions of glucose, and glucose + acetate respectively. In their study over $90 \%$ of the variation in ovulation rate was accounted for by differences in glucose entry rate, leading them to suggest that the ovulatory response to lupin grain is mediated by metabolic pathways involving the synthesis and/or utilization of glucose.

Although deficiencies of the minerals and vitamins depress reproductive performance, evidence for specific effects on ovulation rate is often indirect. For example, Egan (1984), commenting on responses in lamb production to $\mathrm{Zn}$ supplementation of ewes in South Australia, implied that they arise from higher ovulation rates. Similarly the recent report that supplementation of maize-soya-bean diets, normally regarded as containing adequate amounts of available biotin, with a further $300 \mathrm{mg}$ biotin/tonne, increased litter size in pigs (Cromwell et al. 1989) does not distinguish between ovulation and embryo survival. In the case of $\mathrm{Zn}$, an effect on ovulation would, however, be compatible with its implied role as an activator of the enzymes involved in steroidogenesis (Hurley \& Doane, 1989) and its presence in the form of ' $\mathrm{Zn}$ fingers' (two in number) in steroid receptors (Spelsberg et al. 1989).

\section{POSSIBLE MECHANISMS FOR NUTRITIONAL INFLUENCES ON OVULATION RATE}

The higher ovulation rates observed in ewes in good as opposed to poor body condition reffect their greater numbers of large ovarian follicles in the late luteal phase of the preceding oestrous cycle (Rhind \& McNeilly, 1986; Rhind et al. 1989 c; Xu et al. 1989). However, attempts to link quantitative information on follicular growth with contemporary changes in gonadotrophin secretion, on the basis that peripheral concentrations are a reasonable index of secretion (Findlay \& Clarke, 1987), produces a confused picture. Rhind \& McNeilly (1986) observed that increases in ovulation rate arising from improved body condition were accompanied by higher circulating concentrations of FSH during the late luteal and follicular phases of the oestrous cycle, yet in other studies (Rhind et al. 1989c; $\mathrm{Xu}$ et al. 1989) this was not the case. For current plane of nutrition effects, the influence of a high feeding level on ovulation rate appeared to be mediated by an enhanced LH pulse frequency during the follicular phase (Rhind et al. 1985), but a subsequent experiment (Rhind et al. 1989 a) showed that this increase in ovulation rate could occur in the absence of any discernible effects on either LH or FSH. Similarly the stimulating effect on ovulation rate in the ewe of short-term supplements of dietary protein is often (Smith, 1988) but not always (Ritar \& Adams, 1988) associated with increases in the gonadotrophins. For gilts, Flower et al. (1989) reported that the plane of nutrition or flushing effect on ovulation was accompanied by increases in the concentrations of FSH and LH during the $4 \mathrm{~d}$ before oestrus, but even in this species nutritional influences on ovulation rate are not always preceded by differences in the gonadotrophins (Cox et al. 1987).

The hypothesis that the 'flushing' effect on ovulation rate may be mediated by the associated increase in insulin has been tested by administering exogenous insulin to beef heifers (Harrison \& Randel, 1986), ewes (for review, see Smith, 1988) and gilts (Cox et al. 1987). In all three species insulin caused a significant increase in ovulation rate but in line with the 'flushing' effect this was not always accompanied by increases in the plasma gonadotrophins. Where effects on the gonadotrophins have been observed it has tempted 
speculation that insulin may play a role in the supply of nutrients for the synthesis of the GnRH neurotransmitters, particularly as it binds to receptors in those areas of the brain that control GnRH secretion (Steiner, 1987). Alternatively it may act directly on the ovary as suggested by Cox et al. (1987), via enhanced progesterone production by granulosa and luteal cells and androstenedione by thecal cells. The suggestion that insulin increases androstenedione production is interesting in that responses in ovulation rate to dietary protein are associated with increases in the plasma concentrations of both insulin and androstenedione (Smith, 1988). In gilts one of the acute responses to insulin infusion into the peripheral circulation is an increase, within $15 \mathrm{~min}$, in the concentration of oestradiol in the ovarian vein (Britt et al. 1988), again implying a direct ovarian effect. Of course insulin may exercise its effect on the ovary indirectly via elevated growth hormone (GH) and insulin-like growth factor 1 (IGF-1) particularly as high affinity IGF-1 receptors have been located in granulosa cells (Monget et al. 1989) and there is evidence, albeit still somewhat equivocal, that GH may increase ovulation rate in gilts (Kirkwood et al. $1988 \mathrm{~b}$, 1989). It should be noted, however, that when given before puberty GH impaired ovarian development and reduced the incidence of oestrus (Bryan et al. 1989). Alternatively nutritional influences on ovulation rate may be mediated by enhanced hepatic steroid metabolism which blunts the inhibitory feedback action of the steroids on gonadotrophin secretion. For example, nutritional and phenobarbital-induced increases in ovulation rate in ewes were associated with increases in the hepatic microsomal protein concentrations of those enzymes (cytochrome $b_{5}$ and P450) that are involved in the oxidative metabolism of steroids (Thomas et al. 1987).

\section{FERTILIZATION AND EMBRYO SURVIVAL}

Nutritional influences on embryo survival are often interpreted on the assumption that fertilization rates are extremely high and even for diverse nutritional regimens this appears to be so (McKelvey \& Robinson, 1988), the exception being ewes exposed to oestrogenic pastures (Kelly, 1984). Of course the reduction, under certain conditions, in the number of inseminations required to achieve conception in dairy cows by providing a dietary supplement of $\beta$-carotene (Ascarelli et al. 1985), or the increase in calving rate to first insemination in dairy heifers by correcting a selenium deficiency before mating (MacPherson et al. 1987), do not distinguish between effects on fertilization and those on embryo survival. In the case of Se, a deficiency of which is known to reduce embryo survival during implantation in ewes (for review, see Robinson, 1986a), there may be effects also on fertilization operating via alterations in sperm transport, particularly on the more hostile uterine environment that accompanies superovulation. For example, Hurley \& Doane (1989) cite observations where a Se supplement increased the fertilization rate of ova from 41 to $100 \%$ in superovulated beef cows but was without effect in non-superovulated animals. Even for spontaneously-ovulating animals Ferguson \& Chalupa (1989) have expressed concern at the low conception rates to first insemination in high-producing dairy cows and suggest, from their logistic regression analysis on literature values, that a major cause may be an excess of rumen-degradable protein leading to toxic effects of ammonia and its metabolites on gametes and/or the embryo.

In a review of nutritional influences on embryo survival in cattle, sheep and pigs Robinson (1986a) concluded that for all three species a fairly severe and extended period of undernutrition is required to cause significant reductions in the growth and survival of their embryos. Since then there are few new findings to alter this view (for reviews, see Kirkwood \& Thacker, 1988, pigs; Short \& Adams, 1988, beef cattle). In ewes, Rhind et al. 
$(1989 b)$ noted a small increase in ova wastage (fertilization failure and/or embryo mortality), a dramatic decrease $(500 v .1400 \mu)$ in trophoblast length at day 11 but no difference in fetal size at days 21 -26 between those receiving 50 and $150 \%$ of their maintenance needs in early pregnancy. McKelvey \& Robinson $(1986,1988)$ compared the effects of equally diverse nutritional regimens for the first $60 \mathrm{~d}$ of gestation on the survival of high-quality embryos transferred to recipient ewes and found a higher survival in ewes on the low plane of nutrition. They also used embryo transfer in a second experiment to distinguish between nutritional influences in the peri-ovulatory period as opposed to early pregnancy. Although there were significant positive relationships between embryo quality and feeding level and between embryo quality and maternal blood glucose concentrations at the time of ovulation and during the subsequent few days to embryo recovery from the donor ewes, there were no significant relationships between these measures and the subsequent viability of the embryos when transferred to adequately-fed recipient ewes, the overall survival rate being $83 \%$. Thus, the combined results from these two embryotransfer experiments imply that a high plane of nutrition in the pre- and peri-ovulatory periods may be more important to embryo survival than during early pregnancy; indeed high-plane feeding in early pregnancy appears to be detrimental. Results from a number of species now support this general view. For example, high-plane feeding in early pregnancy reduced lambing rate in ewes (Parr et al. 1987), caused an increase in embryo mortality in gilts (Kirkwood \& Thacker, 1988) but not in sows (Toplis et al. 1983) and was accompanied by lower conception rates to first insemination in first-lactation dairy heifers (Ducker et al. 1985). The demonstration by Parr et al. (1987) in ewes and Ashworth (1990) in gilts that the $25-30 \%$ reduction in embryo survival arising from high-plane feeding could be avoided by the administration of exogenous progesterone, one of the key hormones in the maintenance of pregnancy, provides an insight into the mechanisms involved. It would appear that high food intakes, via their stimulatory effects on both hepatic blood flow and the metabolic clearance rate of progesterone (Symonds \& Prime, 1989), cause a decrease in plasma progesterone to levels that may compromise embryo growth and survival; certainly there is ample evidence of lower circulating concentrations on high as opposed to low food intakes in early pregnancy (McKelvey \& Robinson, 1986; Parr et al. 1987, sheep; Prime et al. 1988 , pig). With a significant proportion of embryo mortality in all species occurring during the period of rapid trophoblast elongation that precedes implantation (Bolet, 1986; Stone, 1987), it is tempting to speculate that level of feeding effects which operate through a shift in progesterone may do so by modifying the production of either the trophoblastic proteins and/or the endometrial secretory proteins. Recently Ashworth \& Bazer (1989) showed that the levels of ten of the thirty endometrial proteins that they studied during early pregnancy in ewes were increased by the administration of exogenous progesterone. These proteins, in partnership with those from the trophoblast, form the biochemical dialogue between mother and conceptus that is essential for embryo survival (Bazer, 1989, sheep; Thatcher et al. 1989, cattle; Cross \& Roberts, 1989; Mirando et al. 1990, pigs). The possibility that these proteins and others, such as the IGF-binding proteins which are also secreted by the blastocyst (Corps et al. 1989), may be modified by nutrition, either directly or indirectly via a shift in plasma progesterone, should add a new dimension to investigations of nutritional effects on embryo survival. With regard to the effects of specific dietary ingredients, the recent observations of Bazer \& Zavy (1988) on gilts imply that riboflavin may play a specific role in the early development of the embryo in that a daily supplement of $100 \mathrm{mg}$ to a maize-soya-bean diet over the period (days 4-8 following oestrus) that riboflavin concentrations in uterine flushings exhibit a dramatic transitory increase was accompanied by a significant improvement in embryo survival. Similarly, in view of the essential role of folic acid in DNA and RNA synthesis it is of interest that the 
prevention of the dramatic fall in serum folates noted to occur on some feeding regimens in multiparous sows between weaning and mating and during early pregnancy appeared to enhance embryo survival (Matte et al. 1984).

\section{FETAL GROWTH}

Estimates for the rates of accretion of specific nutrients in the fetus(es) form the basis of the factorial method of estimating dietary needs for fetal growth (see Agricultural Research Council, 1980, cattle and sheep; Agricultural Research Council, 1981, pigs). These can now be augmented with new findings on fetal growth in modern pig genotypes (Noblet et al. 1985), highly prolific ewes carrying up to four fetuses (Robinson, 1985), red deer (Adam et al. 1988) and goats (McDonald et al. 1988). Similarly new estimates for the efficiencies of utilization of ME for pregnancy in the sow (Close $e t$ al. 1985) and of truly digested aminonitrogen for fetal growth in the ewe (Ngongoni et al. 1989) may also modify some of the current estimates of needs. So too may the observation that in the ewe pregnancy per se enhances the amount of amino- $\mathrm{N}$ arriving in the small intestine (Gonzalez et al. 1985; Faichney \& White, 1988; Weston, 1988). Of course tables of dietary needs merely provide useful nutritional guidelines as feeding regimens rarely meet or indeed attempt to meet exact requirements for fetal growth at each stage of pregnancy. For this reason information on the vulnerability of fetal growth to changes in maternal nutrition is invaluable as it relates directly to viability at birth.

\section{PLANE OF NUTRITION EFFECTS}

Of the farmed species, the cow lies at the upper end of the maternal weight range but the nutrient requirements for her single fetus are readily met either as a consequence of the practice of high-plane feeding in late pregnancy to build up body reserves for lactation (dairy cows) or from dietary and body tissue sources (Wright et al. 1986) when the subsequent nutrient demands for lactation are relatively small (beef cows). Even in the case of twin-bearing cows Topps et al. (1989) found that a daily ME intake as low as 1.5 times maintenance in late pregnancy did not reduce calf birth weights. At the other end of the maternal weight range is the rabbit in which fetal growth also places a very small demand for nutrients on the doe (Lang, 1981). However, with conception in commercial rabbit production systems occurring the day after parturition, the high nutrient demands for lactation (four times maintenance) can, if not met by adequate food intake, lead to premature regression of the corpora lutea and termination of pregnancy (Lamb, 1985). Where nutrition is adequate (dietary digestible energy (DE) $15.4 \mathrm{MJ} / \mathrm{kg}$ and digestible crude protein $(\mathrm{N} \times 6.25$; DCP) $14.8 \mathrm{~g} / \mathrm{MJ} \mathrm{DE})$ no adverse effects on pregnancy or fetal growth occur and the rapid natural decline in milk production by the doe in the fourth week of lactation coincides with the period of high fetal growth, thus allowing nutrients to be diverted to the gravid uterus (Partridge, 1989).

In the process of developing current feeding strategies for pregnancy in the sow, it was noted that substantial increases in food intake during pregnancy are required to evoke even a small increase in birth weight in this species (English \& Wilkinson, 1982). Also, attempts to boost the energy reserves of newborn piglets by the addition of dietary lipid (inclusion rates from 7.5 to $15 \%$ ) have produced varying results (Seerley, 1984). Thus, current recommended feeding regimens for modern pig genotypes are based on first generation empirical models involving live-weight increments from conception to conception in the order of $35 \mathrm{~kg}$ in the first parity falling to $20 \mathrm{~kg}$ in the fourth parity (Whittemore, 1989). 
Since a loss of body condition during lactation in the sow is inevitable, these live-weight increments are achieved during pregnancy thereby ensuring that fetal growth is an inherent beneficiary of the higher feeding levels.

In contrast to most of the other farmed species, extremes in food intake during pregnancy are a feature of sheep production systems and a knowledge of their effects on fetal growth is essential. Using ewes that were in good body condition $(30 \%$ fat in their fleece-free empty body) at mating, Vincent et al. (1985) found that restriction of food intake to $15 \%$ of maintenance needs from mating until $60 \mathrm{~d}$ of gestation, followed by recommended feeding standards for the remainder of pregnancy, produced evidence of arrested growth in the proximal tibial metaphyses of the fetus and reduced lamb birth weight and viability by 15 and $36 \%$ respectively. In a review of experiments involving less severe feed restrictions (0.3-0.5 times maintenance) for a shorter period (first $30-40 \mathrm{~d}$ of gestation) Robinson \& McDonald (1989) concluded that they depressed contemporary fetal growth by about $10 \%$ with this effect carrying through to day 90 but disappearing by the time of birth, about 2 months later. Nutritional influences during mid-pregnancy in the ewe are particularly fascinating. At this time a mild degree of undernutrition for ewes that are in very good body condition at mating enhances the growth of the placenta and subsequent lamb birth weight (Faichney \& White, 1987) but the opposite is true for young ewes and those in poor condition at mating (Russel et al. 1981).

In the ewe, responses in birth weight to alterations in $\mathrm{ME}$ intake in late pregnancy vary greatly with differences in genotype and maternal reserves plus a positive relationship between the ME concentration of the diet and the efficiency $\left(K_{c}\right)$ of ME utilization for conceptus growth appearing to contribute to the variation (Robinson \& McDonald, 1989). Failure to increase energy intakes to meet the needs of the rapidly-growing fetus(es) is reflected in either a gradual slowing down of prenatal growth or mobilization of body reserves to such an extent that there is no discernible effect on the fetus(es) (Robinson \& Aitken, 1986). In contrast a severe and abrupt restriction in food intake, typical of that caused by a rapid deterioration in weather conditions in hill and upland environments, can reduce fetal growth by $30-40 \%$ within $3 \mathrm{~d}$ or in some cases cause a complete cessation in growth, as determined by in vivo estimates of the daily changes in the crown-rump lengths of individual fetuses (Mellor, 1987). For relatively short periods of severe undernutrition of 1 week duration growth rates return to normal when food intake is increased, but for longer periods this is not the case. For example, Mellor \& Murray (1982) found that following $16 \mathrm{~d}$ in which the daily prefeeding levels for maternal blood glucose were only $50 \%$ of those for well-fed controls, fetuses lacked the ability to return to normal growth rates when food intake was increased.

\section{SPECIFIC NUTRIENTS}

The practical importance of maternal nutrition on ovine fetal growth has encouraged investigations into the role of specific nutrients. Robinson (1983) noted that the adverse effect on size at birth of low-plane feeding during late pregnancy is much more pronounced when accompanied by low protein intakes. More recently Kleemann et al. (1988) using highly prolific Booroola $\times$ Merino ewes have obtained a birth-weight response to the feeding of lupin grains in late pregnancy, again implying a response to protein. Barry \& Manley (1985) have shown that while a high-quality pasture could meet the glucose needs of triplet-bearing ewes in late pregnancy there was a substantial deficit in the supply of amino acids leading to a daily loss of $8 \mathrm{~g} \mathrm{~N}$ from the maternal body. This implies that the major source of amino acids, namely microbial protein, failed to meet fetal needs. In this context Robinson et al. (1985) compared their findings for the rates of accretion of amino 
acids in the fetuses of prolific ewes with the corresponding supply of each amino acid from microbial protein. They concluded that there was a deficit in cystine which was unlikely to be fully met by interconversion from methionine when, as a consequence of a low intake of energy, it too was in short supply. Rates of accretion of histidine also exceeded microbial supply. Of course more research will be needed to reconcile these observations with the preliminary report by Bell et al. (1988) that a fetal intragastric infusion of glucose alone was as effective as a combined infusion of glucose and amino acids in sustaining fetal growth in underfed ewes.

Despite the high rates of accretion of the major mineral elements, notably calcium, in the fetal skeleton a moderate deficiency of dietary $\mathrm{Ca}$ has no effect on fetal growth in the ewe (for review, see Robinson, $1986 b$ ), mobilization from the maternal skeleton acting as a very effective buffer. Recently a novel parathyroid hormone (PTH)-like peptide which may sustain the relative hypercalcaemia of the fetus has been observed in the parathyroid glands of ovine fetuses (Loveridge et al. 1988) and their placentas (Rodda et al. 1988).

In both the ewe and cow, where the mobilization of skeletal Ca during lactation appears to be obligatory (Braithwaite, 1983), the gradual reawakening during late pregnancy of the metabolic pathways involved in mobilization without precipitating hypocalcaemia is a major challenge in modern production systems. The condition is more prevalent in older animals where the primary cause appears to be a reduction in the expression of the 1,25dihydroxycholecalciferol receptors (Horst et al. 1989) that are involved in Ca absorption from the gut and resorption from bone.

Field observations made in Australia in the early 1980s suggesting that deficiencies of $\mathrm{Zn}$ and iodine might be responsible for impaired reproductive performance in ewes triggered studies on their effects on fetal growth. Masters \& Moir (1983) showed that ewes given a low-Zn diet $(4 \mathrm{mg} / \mathrm{kg}$ ) produced lambs that were $17 \%$ lighter at birth than those receiving an adequate- $\mathrm{Zn}$ diet $(50 \mathrm{mg} / \mathrm{kg})$. Dramatic reductions were also noted in the activities of some of the $\mathrm{Zn}$-dependent enzymes, notably hepatic alkaline phosphatase $(E C$ 3.1.3.1) and thymic thymidine kinase ( $E C$ 2.7.1.21). Inertia of the uterine muscles and protracted parturition can also be a feature of $\mathrm{Zn}$ deficiency (for review, see Apgar, 1985). The extensive studies on the effects of I deficiency $(8-15 \mu \mathrm{g} \mathrm{I} / \mathrm{kg}$ feed instead of the recommended $500 \mu \mathrm{g}$ ) have been reviewed by Hetzel \& Mano (1989). These show depressions in fetal growth from mid-pregnancy onwards resulting in a 20-25\% reduction in lamb birth weight, poor wool growth and retarded myelination in the cerebral hemispheres and brainstem.

\section{MAMMOGENESIS AND COLOSTRUM PRODUCTION}

Since the growth of virtually all of the lobule-alveolar epithelial cell system of the mammary gland in ruminants takes place during pregnancy (Forsyth, 1986) it is not surprising that undernutrition in late pregnancy reduces mammary development and colostrum production (Mellor, 1987). Equally understandable is the finding that the detrimental effects of a maternal energy deficit on the supply of colostrum in the ewe at parturition can be ameliorated by increasing her supply of amino acids through provision of a dietary supplement of rumen UDP (Robinson \& McDonald, 1989). Boosting the energy content of colostrum in those species (pig and sheep) in which starvation can be a major cause of neonatal mortality is readily achieved in both the sow (Seerley, 1984) and ewe (J. J. Robinson, unpublished results) by the inclusion of dietary lipid which, in the case of the ewe, needs to be protected from hydrolysis in the rumen.

In well-nourished ewes colostrum accumulates in the mammary glands during the last 
few days of pregnancy, thereby ensuring that an adequate supply (about $50 \mathrm{ml} / \mathrm{kg}$ birth weight) is immediately available to the newborn lamb(s). Undernutrition not only reduces the yield of colostrum but, if severe, can delay the onset of lactogenesis, with the suggestion that the causal mechanisms are not restricted entirely to a lack of nutrients but may also involve the delaying effects of undernutrition on the prepartum fall in progesterone (Mellor et al. 1987).

One of the most intriguing nutritional influences on mammogenesis and subsequent milk production is the detrimental effect on both of high-plane feeding during the prepubertal phase (Johnsson \& Hart, 1985; Umberger et al. 1985, sheep; Johnsson \& Obst, 1984, beef heifers; Foldager \& Sejrsen, 1987; Johnsson, 1988, dairy heifers). The mechanisms involved are complex but all the evidence to date implicates the reduction in plasma $\mathrm{GH}$ that accompanies high-plane feeding before puberty (Johnsson, 1988), thus prompting Forsyth (1989) to speculate that the effects on mammogenesis may be via GH-dependent IGF-1.

\section{NEONATAL VIABILITY}

Maternal nutrition, through its effects on fetal metabolism, fetal growth and colostrum production plays a key role in neonatal viability. Undernutrition reduces uterine blood flow and uteroplacental glucose uptake (Bell, 1984; ewe; Reynolds et al. 1986, cow) leading to fetal hypoglycaemia and hypoxemia. The accompanying shifts in fetal hormone secretion, namely the decrease in insulin and increases in GH, ACTH and corticosterone, play their part in modulating the effects of maternal undernutrition on the growth and development of the fetus (Bassett \& Fletcher, 1982). In species such as the rabbit, and more importantly the sheep, because of the low environmental temperatures into which many lambs are born, brown adipose tissue (BAT) provides an important thermogenic response for survival (Alexander, 1986). Its reduced synthesis during fetal undernutrition (Robinson \& McDonald, 1989) and the associated hypoxemia-induced depression in its neonatal metabolism coupled with the fact that those features of fetal undernutrition already mentioned (low insulin and increased corticosterone) would be expected to inhibit BAT thermogenesis (Trayhurn, 1989), provides a glimpse of some of the mechanisms whereby maternal nutrition may influence neonatal survival. Of further relevance to these mechanisms may be the observation that the activity of iodothyronine 5 -deiodinase ( $E C$ 3.8.1.4), the enzyme that stimulates the conversion of thyroxine (T4) to the active thyroid hormone, triiodothyronine (T3), which is used both locally and also as a source of T3 for other tissues in the body, is stimulated by insulin (Silva \& Larsen, 1986). In view of these mechanisms it is interesting that a positive correlation between neonatal survival and plasma T3 concentrations in lambs has been reported by Wollny et al. (1986) in conditions where there is no reason to suspect that the cause was I deficiency per se. From field observations in Australia, Caple \& Nugent (1982) obtained a positive correlation between thyroxine (T4) concentrations and neonatal lamb viability, the lower critical value for plasma T4 being $50 \mu \mathrm{g} / \mathrm{l}$. However, in this case the cause was considered to be functional hypothyroidism arising from inadequate I nutrition of the ewe. In this regard the recent observations of Arthur et al. (1990), albeit on rats, that the adverse effect of I deficiency on T4 synthesis is accentuated by a concomitant Se deficiency is particularly pertinent, in that Se deficiency reduces neonatal viability in both lambs and calves (Agricultural Research Council, 1980).

Although body lipid constitutes $60-70 \%$ of the energy available to the newborn lamb between birth and sucking, liver and muscle glycogen at about $15 \%$ is also important and, in quantitative terms, it too is reduced by maternal undernutrition (Alexander, 1986). 
Again fetal insulin stimulates glycogenesis, but as pointed out by Jones \& Rolph (1985) other factors with insulin-like action are probably involved; a possible candidate, in view of the identification of its mRNAs in fetal liver, intestine and stomach (Simmen et al. 1989), may be IGF-I. Glycogen is the major energy source in the newborn piglet. However, dietary-induced increases in its quantity, even when they are as dramatic as the $41 \%$ increase in total liver glycogen observed recently by Seerley (1989) for the piglets of sows given a $100 \mathrm{~g}$ dietary lipid supplement $/ \mathrm{kg}$ from $80 \mathrm{~d}$ of gestation, do not necessarily improve piglet survival. In this study piglet mortality on the control diet was well below $20 \%$, the value above which dietary-induced shifts in glycogen reserves are likely to be of benefit to survival.

In addition to its effects on fetal metabolism and the energy reserves of the newborn, the detrimental influence of maternal undernutrition on size at birth plays a direct role in survival and this is particularly true for the lamb. As birth weight decreases the ratio between the potential for heat exchange (i.e. surface area) and that for heat production (i.e. body weight) increases thereby making small lambs vulnerable to death from hypothermia in a cold environment and from dehydration and heat stress in a hot environment (Alexander, 1986). These detrimental influences are accentuated by the adverse effect of maternal undernutrition on the growth of the birthcoat (Black, 1983). Nonetheless apart from its effect on neonatal survival the longer-term effects of intrauterine growth retardation in those lambs that survive are likely to be small. Cellular hyperplasia is still active in all tissues of the lamb at birth leaving the way open for the prenatal effects to be largely concealed by good post-natal nutrition (Robinson \& Aitken, 1986). This is in contrast to the pig where muscle fibre hyperplasia ceases between 85 and $95 \mathrm{~d}$ of gestation, at which point Wigmore \& Stickland (1983) observed a $17 \%$ reduction in total fibre numbers in the semitendinosus muscle of the smallest as compared with the largest fetuses in a litter.

In sheep production systems many of the detrimental effects of maternal undernutrition on the newborn can be avoided by an adequate intake of colostrum at birth but in the absence of human intervention the nutritionally-induced delay in colostrum production removes that option and predisposes those that survive to subsequent infection. Indeed less-obvious dietary deficiencies may do likewise. For example, in the absence of an effect on lamb birth weight, Fisher \& MacPherson (1986) present findings to suggest that the high incidence of perinatal mortality in lambs from cobalt-deficient ewes (serum vitamin $\mathbf{B}_{12}<$ $300 \mathrm{ng} / \mathrm{l}$ and serum methylmalonic acid $>4.6$ but $<15.0 \mu \mathrm{mol} / \mathrm{l}$; McMurray et al. 1985) is due to an impairment in the immune status of the ewe and thus in the passive immunity acquired by the lamb. In sows receiving current recommended allowances for the trace elements and vitamins, Hayek et al. (1989) have reported that an intramuscular injection on day 100 of gestation of $5 \mathrm{mg} \mathrm{Se}$ or $1 \mathrm{~g}$ vitamin E as DL- $\alpha$-tocopherol enhanced immunoglobulin transfer to their progeny.

\section{PARTURITION-TO-REBREEDING INTERVAL}

Reducing the parturition-to-rebreeding interval is probably the single most important area that remains for improving the reproductive efficiency of sheep, goats, red deer, cattle and pigs. In all five species nutrition plays an important part in the initiation of post-partum ovarian activity. Poor nutrition during lactation, leading to a failure by red deer to regain their threshold body-weight for conception within their restricted breeding season, delays oestrous cyclicity until the following year (Hamilton \& Blaxter, 1980) and the same is true for sheep and goats in some adverse environments (Doney et al. 1982). In the absence of 
major seasonal or, more accurately, photoperiodic effects on breeding activity, which is largely the case for cattle and pig production systems, the quest for feeding strategies that evoke a rapid return to normal oestrous cyclicity is now a major research goal. Although deficiencies of specific minerals such as $\mathrm{Ca}$, phosphorus, copper, iron and I may cause postpartum anoestrus (Surerdra Singh \& Vadnere, 1987), low intakes of energy and an imbalance in dietary protein are more common predisposing factors. Many high-yielding dairy cows remain in negative energy balance for the first $70 \mathrm{~d}$ of lactation (Villa-Godoy et al. 1988), but interestingly it is during the first 2-3 weeks, when the deficit is at its greatest, that the positive relationship between its magnitude and the interval to first ovulation is established (Butler \& Smith, 1989). In quantitative terms the delay in ovulation is about $0.7 \mathrm{~d}$ for each increase of $1 \mathrm{MJ}$ in the average daily deficit over the first $20 \mathrm{~d}$ of lactation. Depending on the extent of their degradation in the rumen dietary protein supplements may modify this relationship. For example, undegraded proteins that enhance milk yield and therefore by implication stimulate the mobilization of body fat in early lactation would be expected to accentuate the energy deficit and delay rebreeding accordingly. Highly degradable proteins may also delay rebreeding but here there is the suggestion that the causal mechanisms involve a delay in uterine involution (Carroll et al. 1988; Ferguson \& Chalupa, 1989). Although short post-partum intervals to first ovulation and to the resumption of normal oestrous cyclicity (about 3 and 4 weeks respectively) are a prerequisite for a high conception rate at first insemination about 1 month later, other factors are also important. From a study on first-lactation dairy heifers, Ducker et al. (1985) concluded that a high milk yield and/or an increasing pattern of yield at the time of insemination was detrimental to conception. Of course the minimum rebreeding interval may not be the most profitable, and to this end Goodall \& McMurray (1984) have incorporated different feeding strategies, feed costs, calving dates and reproductive performance values into a computer model to predict the financial advantage or disadvantage of reducing the rebreeding interval.

For beef cows that suckle their calves a protracted post-partum anoestrus of up to 90 $\mathrm{d}$ is not uncommon and is the major cause of poor reproductive efficiency (Wright et al. 1987). Low-plane feeding not only extends the time to first ovulation but increases its between-animal variability (Easdon et al. 1985), thereby making it difficult to optimize subsequent nutritional regimens on a herd basis. In the study of Wright et al. (1987) the average duration of the post-partum anoestrus was extended by $43 \mathrm{~d}$ for each reduction in body condition score (equivalent to $53 \mathrm{~kg}$ body lipid) at calving. Low feeding levels in the post-partum period increased the proportion of thin but not fat cows that remained anoestrous. Inclusion of $80 \mathrm{~g}$ dietary lipid $/ \mathrm{kg}$ to boost energy intake and provide a source of cholesterol for luteal progesterone synthesis (Williams, 1989) increased progesterone production by GnRH-induced corpora lutea in the fourth week following calving and prevented premature luteal regression. Interestingly lipid supplementation also increased the incidence of transitory elevations in progesterone before $\mathrm{GnRH}$ administration. Low protein intakes also delay oestrus. Sasser et al. (1988) compared daily intakes of 960 and $320 \mathrm{~g}$ and observed a $29 \%$ reduction in behavioural oestrus for those on the low protein intake. Furthermore, those showing oestrus did so on average $11 \mathrm{~d}$ later and had a conception rate of only $32 \%$ compared with $74 \%$ for their high-protein counterparts.

The effect of nutrition on the duration of the interval between weaning and rebreeding in pigs is now a major research area, not least because delayed resumption of oestrous activity is one of the main reasons for premature culling from the breeding herd (Mullan et al. 1989). Low-plane feeding during lactation ( $<45 \mathrm{MJ} \mathrm{DE} / \mathrm{d})$ increases the weaning to oestrus interval (King, 1987). The effect is more pronounced in first-litter sows than in multiparous sows and within the 'first-litter' category is further accentuated in those mated 
for the first time at a young age (King \& Dunkin, 1986 a). While a lactation feeding strategy that is close to ad lib. may be favoured for minimizing the weaning to rebreeding interval when the diet contains 13.2 MJ DE/ $\mathrm{kg}$ (Eastham et al. 1988), the ad lib. feeding of a diet with a higher DE concentration (15.6 MJ) may actually extend the interval (Kirkwood et al. 1988a). For sows given free access to food during lactation there is an inverse relationship between voluntary intake and body condition leading to large weight losses during lactation for those in good body condition at farrowing. Although these losses do not necessarily extend the rebreeding interval (Mullan \& Williams, 1989) they raise questions about what is the ideal body condition at farrowing. In this regard Yang et al. (1989) opt for a target backfat thickness (P2) at parturition of $20 \mathrm{~mm}$ (1 mm is equivalent to $3 \mathrm{~kg}$ body lipid) in primiparous sows followed by ad lib. feeding during lactation. This gave a weaning to oestrus interval of approximately $8 \mathrm{~d}$ and exploited the principle that the higher the energy intake during lactation the shorter the post-weaning interval to oestrus (Johnston et al. 1989). Boosting the energy intake by the inclusion of a lipid supplement appears to have little additional benefit (Shurson et al. 1986) but evidence is now accumulating to emphasize the importance of dietary protein in reducing the rebreeding interval (King, 1987; Brendemuhl et al. 1987; King \& Martin, 1989). In reviewing the literature for primiparous sows, King (1987) observed a highly significant relationship, $I=$ 3.44 $P_{L}+9 \cdot 6$, between the weaning to oestrus interval $(I ; \mathrm{d})$ and the estimated loss of body protein during lactation $\left(P_{L} ; \mathrm{kg}\right)$. For dietary protein intake $\left(P_{t}, \mathrm{~g} / \mathrm{d}\right)$ the relationship, which was also highly significant, was $I=-0.032 P_{i}+32.5$ for protein intakes in the range $220-745 \mathrm{~g} / \mathrm{d}$.

\section{NUTRITIONAL INFLUENCES ON POST-PARTUM ENDOCRINE CHANGES}

Nutritional effects on the establishment of oestrous cyclicity after parturition operate by modifying the timing and magnitude of the general hormone changes that occur in late pregnancy and during early lactation. These changes have been outlined in detail by Nett (1987) and will only be briefly summarized here. Although there is no diminution in the number of $\mathrm{GnRH}$ receptors in the cells of the pituitary gland in late pregnancy and the hypothalamus is amply equipped with GnRH there is a very low content of pituitary LH. This arises either directly from the suppression of LH synthesis by the steroids of pregnancy or indirectly from their inhibitory effects on GnRH secretion and thus on the trophic stimulus of GnRH on LH synthesis. The rapid decrease in oestradiol at parturition removes its negative feedback on the hypothalamic-pituitary axis, thereby promoting the synthesis of mRNAs for the LH subunits followed by a rapid increase in pituitary LH content. Increases in hypothalamic GnRH secretion follow and an increasing incidence of $\mathrm{LH}$ pulses is detectable in the peripheral circulation, each pulse triggering the release of oestradiol from the ovarian follicles (Peters \& Perera, 1989). Depending on the species, sucking or perhaps more specifically suckling frequency (Loudon, 1987) inhibits the episodic release of $\mathrm{LH}$ probably via the secretion of hypothalamic opioid peptides such as $\beta$-endorphin (Gordon et al. 1987). In practical pig production systems suckling completely suppresses ovarian activity, but provided it does not coincide with seasonal anoestrus it merely delays the interval to ovulation in sheep and deer; likewise for cattle that suckle their calves.

Nutrition modifies the preceding neuroendocrine changes and for all species a common feature of this modification is an alteration in the frequency of the episodic release of $\mathrm{LH}$. In beef cows the induction of anoestrus by low-plane feeding is accompanied by a decrease in the frequency of LH pulses (Richards et al. 1989). Similarly, in sows protracted weaning 
to oestrus intervals that arise either from low intakes of energy (Armstrong et al. 1986) or from a specific protein deficiency (King \& Martin, 1989) during lactation are characterized by an abnormally low frequency of LH pulses in the immediate preweaning period. There is no evidence that low-plane feeding during early lactation inhibits the pituitary supply of LH (Kirkwood et al. 1987 a, pigs; Rutter \& Manns, 1987, cattle). Likewise there does not appear to be any defect in the ability of the ovarian follicle to secrete oestrogen in response to LH, or of their granulosa and thecal cells to increase their LH receptor populations in response to progesterone (Inskeep et al. 1988), thus ensuring that they become fully functional corpora lutea. All this implies that nutritional regimens that delay rebreeding do so largely via an inhibition of GnRH secretion. The identification of the mechanisms whereby the body monitors, processes and transmits the information on its nutritional status during the post-partum period to the GnRH neuron is now a major research priority. Serum IGF-1 concentrations reflect the nutritional status of the post-partum beef cow (Rutter et al. 1989), but whether or not they play an active role in the synthesis or activation of the GnRH neurotransmitters is not known.

\section{CONCLUSIONS AND PERSPECTIVES}

Advances in our knowledge of the influence of nutrition on the reproduction of farm animals emanate mostly from experiments that have concentrated on only one small part of the overall reproductive cycle. Few experiments consider the implications of a nutritional effect at one point to events later on in the same breeding cycle, and fewer still to the overall reproductive life-span of the animal. Thus, it has been convenient in the present review to segregate information and present it in relation to a number of fairly well-defined physiological states within the reproductive cycle. Even when presented in this format it is clear that nutritional regimens that maximize a response at one point can have carry-over effects that are counter-productive at a later stage. A good example of this is the detrimental effect on mammogenesis and subsequent milk yield of the high-plane feeding in early life that can be used to induce precocious puberty and early breeding in dairy heifers and ewe lambs. Another is the stimulating effect of high-plane feeding on ovulation rate in gilts and ewes which, if sustained into early pregnancy, is detrimental to embryo survival. Nutritionally-stimulated maxima for ovulation rate in the ewe often fail to recognize the inability of some environments to provide adequate nutrients to sustain the associated higher demands of late pregnancy. The same is true for the more prolific genotypes of ewe, but here the nutrient demands of the gravid uterus often exceed those that can be supplied by the digestive tract, even when the diet is of the highest quality. There are many other examples of what may appear to be highly desirable nutritional responses for one physiological state that are counter-productive to reproduction as a whole. Thus, the successful application of new findings on the responses in reproduction to nutrient supply requires a forward projection of their longer-term implications for the overall well-being of breeding stock and their progeny.

At the more fundamental level, during the last few years researchers have become increasingly interested in the underlying mechanisms involved in nutritionally-mediated responses in reproduction, and the present review has attempted to reflect this shift in emphasis. Although a great deal of information is now accumulating on the influences of nutrition on the circulating concentrations of a whole range of blood metabolites, knowledge is still awaited on how alterations in body metabolism are translated into the neuronal mechanisms that trigger events such as puberty, an increase in ovulation rate or the resumption of ovarian activity following parturition. Unravelling these mechanisms 
and others, such as how nutrition modifies the fine balance in the biochemical dialogue between mother and embryo that is so essential for the successful establishment of pregnancy, are exciting challenges.

\section{REFERENCES}

Adam, C. L., McDonald, I., Moir, C. E. \& Smart, R. I. (1988). Foetal development in red deer (Cervus elaphus). 2. Chemical composition of the foetus and associated tissues. Animal Production 46, 139.146.

Adam, C. L. \& Moir, C. E. (1985). Effect of winter nutrition of young farmed red deer on their subsequent growth at pasture. Animal Production 40, 135141.

Agricultural Research Council (1980). The Nutrient Requirements of Ruminant Livestock: Technical Review, 2nd ed. Slough: Commonwealth Agricultural Bureaux.

Agricultural Research Council (1981). The Nutrient Requirements of Pigs, 2nd ed. Slough: Commonwealth Agricultural Bureaux.

Aherne, F. X. \& Kirkwood, R. N. (1985). Nutrition and sow prolificacy. Journal of Reproduction and Fertility 33, $169-183$.

Alexander, G. (1986). Physiological and behavioural factors affecting lamb survival under pastoral conditions. In Factors Affecting the Survival of Newborn Lambs, pp. 99-114 [G. Alexander, J. D. Barker and J. Slee, editors]. Luxembourg: Commission of European Communities.

Alkass, J. E., Bryant, M. J. \& Walton, J. S. (1982). Some effects of level of feeding and body condition upon sperm production and gonadotropin concentrations in the ram. Animal Production 34, 265277.

Amann, R. P. (1987). Function of the epididymis in bulls and rams. Journal of Reproduction and Fertility. Suppl. 34, $115-131$.

Apgar, J. (1985). Zinc and reproduction. Annual Review of Nutrition 5, 4368.

Armstrong, J. D., Britt, J. H. \& Kraeling, R. R. (1986). Effect of restriction of energy intake during lactation on body condition, energy metabolism, endocrine changes and reproductive performance in primiparous sows. Journal of Animal Science 63, 1915-1925.

Arthur, J. R., Nicol, F., Rae, P. W. H. \& Beckett, G. J. (1990). Effects of combined selenium and iodine deficiencies on the thyroid gland of the rat. Journal of Endocrinology 124, Supplement, abstract no. 240.

Ascarelli, I., Edelman, Z., Rosenberg, M. \& Folman, Y. (1985). Effect of dietary carotene on fertility of highyielding dairy cows. Animal Production 40, 195-207.

Ashworth, C. J. (1990). Effect of pre-mating nutritional status and post-mating progesterone supplementation on early pregnancy in large white gilts. Animal Production 50, 560 .

Ashworth, C. J. \& Bazer, F. W. (1989). Changes in ovine conceptus and endometrial function following asynchronous embryo transfer or administration of progesterone. Biology of Reproduction 40, 425433.

Baidoo, S. K. \& Aherne, F. X. (1988). Sow weight and backfat loss in lactation; effects on the occurrence and the endocrinology of the post weaning estrus. Proceedings of the I/th International Congress on Animal Reproduction and Artificial Insemination 2, Paper number 7.

Barry, T. N. \& Manley. T. R. (1985). Glucose and protein metabolism during late pregnancy in triplet-bearing ewes given fresh forages ad lib. 1. Voluntary intake and birthweight. British Journal of Nutrition 54, 521-533.

Bassett, J. M. \& Fletcher, J. M. (1982). Hormonal regulation of fetal metabolism and growth: the roles of pancreatic and adrenal hormones. In Biochemical Development of the Foetus and Neonate, pp. $393-423$ [C. T. Jones, editor]. Amsterdam: Elsevier Biomedical Press.

Bazer, F. W. (1989). Establishment of pregnancy in sheep and pigs. Reproduction, Fertility and Development 1. 237. 242.

Bazer, F. W. \& Zavy, M. T. (1988). Supplemental riboflavin and reproductive performance of gilts. Journal of Animal Science 66, Suppl. 1, 324.

Bell, A. W. (1984). Factors controlling placental and foetal growth and their effects on future production. In Reproduction in Sheep, pp, 144152 [D. R. Lindsay and D. T. Pearce, editors]. Canberra: Australian Academy of Science and Australian Wool Corporation.

Bell, A. W., Slepetis, R., Schnoknech, P. A. \& Vatnick, I. (1988). Nutritional and placental influences on prenatal growth in sheep. Proceedings of the Cornell Nutrition Conference for Feed Manufacturers, pp. 103-108.

Black, J. L. (1983). Growth and development of lambs. In Sheep Production, pp. 21-58 [W. Haresign, editor]. London: Butterworths.

Bolet, G. (1986). Timing and extent of embryonic mortality in pigs, sheep and goats: genetic variability. In Embryonic Mortality in Farm Animals, pp. 1243 [J. M. Sreenan and M. G. Diskin, editors]. Dordrecht: Martinus Nijhoff Publishers.

Braithwaite, G. D. (1983). Calcium and phosphorus requirements of the ewe during pregnancy and lactation. 1. Calcium. British Journal of Nutrition 50, 711-722.

Brendemuhl, J. H., Lewis, A. J. \& Peo, E. R. (1987). Effect of protein and energy intake by primiparous sows during lactation on sow and litter performance and sow serum thyroxine and urea concentrations. Journal of Animal Science 64, 10601069. 
Britt, J. H., Armstrong, J. D. \& Cox, N. M. (1988). Metabolic interfaces between nutrition and reproduction in pigs. Proceedings of the 1lih International Congress on Animal Reproduction and Artificial Insemination 5 , 117-125. University College, Dublin.

Bronson, F. H. \& Manning, J. (1988). Food, energy expenditure and puberty in female rats. Proceedings of the IIth International Congress on Animal Reproduction and Artificial Insemination 5, 109-116. University College, Dublin.

Brooks, A. L., Morrow, R. E. \& Youngquist, R. S. (1985). Body composition of beef heifers at puberty. Theriogenology 24, 235- 250.

Bryan, K. A., Hammond, J. M., Canning, S., Mondschein, J., Carbaugh, D. E., Clark, A. M. \& Hagen, D. R. (1989). Reproductive and growth responses of gilts to exogenous porcine pituitary growth hormone. Journal of Animal Science 67, 196-205.

Butler, W. R. \& Smith, R. D. (1989). Interrelationships between energy balance and postpartum reproductive function in dairy cattle. Journal of Dairy Science 72, 767. 783.

Caple, I. W. \& Nugent, G. F. (1982). Relationships between plasma thyroxine concentrations and the responses of newborn lambs to hypothermia. Proceedings of the Australian Society of Animal Production 14, 657.

Carroll, D. J., Barton, B. A., Anderson, G. W. \& Smith, R. D. (1988). Influence on protein intake and feeding strategy on reproductive performance of dairy cows. Journal of Dairy Science 71, 3470-3481.

Close, W. H., Noblet, J. \& Heavens, R. P. (1985). Studies on the energy metabolism of the pregnant sow. 2. The partition and utilization of metabolizable energy intake in pregnant and non-pregnant animals. British Journal of Nutrition 53, 267279.

Corps, A. N., Littlewood, C. J. \& Brown, K. D. (1989). IGF-binding proteins from pig pre-implantation blastocysts. In Biotechnology in Grow'th Regulation, pp. 252 [R. B. Heap, C. G. Prosser and G. E. Lamming. editors]. London: Butterworths.

Cox, N. M., Stuart, M. J., Althen, T. G., Bennett, W. A. \& Miller, H. W. (1987). Enhancement of ovulation rate in gilts by increasing dietary energy and administering insulin during follicular growth. Journal of Animal Science 64, 507-516.

Cromwell, G. L., Stahly, T. S. \& Randolph, J. R. (1989). Supplemental biotin for sows during gestation and lactation. In Swine Research Report no. 321, pp. 5859 [G. L. Cromwell, editor]. Lexington, KY: University of Kentucky.

Cross, J. C. \& Roberts, R. M. (1989). Porcine conceptuses secrete an interferon during the preattachment period of early pregnancy. Biology of Reproduction 40, 1109-1118.

Dailey, R. A., Deaver, D. R. \& Goodman, R. L. (1987). Neurotransmitter regulation of luteinizing hormone and prolactin secretion. Journal of Reproduction and Fertility, Suppl. 34, 17-26.

Day, M. L., Imakawa, K., Zalesky, D. D., Kittok, R. J. \& Kinder, J. E. (1986). Effects of restriction of dietary energy intake during the prepubertal period on secretion of luteinizing hormone and responsiveness of the pituitary to luteinizing hormone-releasing hormone in heifers. Journal of Animal Science 62, 1641-1648.

den Hartog, L. A. \& Noordewier, G. J. (1984). The effect of energy intake on age at puberty in gilts. Netherlands Journal of Agricultural Science 32, 263-280.

Doney, J. M., Gunn, R. G. \& Horak, F. (1982). Reproduction. In Sheep and Goal Production, pp. 5780 [I. E. Coop, editor]. Amsterdam: Elscvier Scientific Publishing Company.

Ducker, M. J., Haggett, R. A., Fisher, W. J., Morant, S. V. \& Bloomfield, G. A. (1985). Nutrition and reproductive performance of dairy cattle. 1 . The effect of level of feeding in late pregnancy and around the time of insemination on the reproductive performance of first lactation dairy heifers. Animal Production 41, 1-12.

Dyck, G. W. (1988). Factors influencing sexual maturation, puberty and reproductive efficiency in the gilt. Canadian Journal of Animal Science 68, 1-13.

Dýrmundsson, Ó. R. (1987). Advancement of puberty in male and female sheep. In New Techniques in Sheep Production, pp. 6576 [I. F. M. Marai and J. B. Owen, editors]. London: Butterworths.

Easdon, M. P., Chesworth, J. M., Aboul-Ela, M. B. E. \& Henderson, G. D. (1985). The effect of undernutrition of beef cows on blood hormone and metabolite concentrations post partum. Reproduction, Nutrition, Développement 25, 113-126.

Eastham, P. R., Smith, W. C., Whittemore, C. T. \& Phillips, P. (1988). Responses of lactating sows to food level. Animal Production 46, 71-77.

Egan, A. R. (1984). Nutrition for reproduction. In Reproduction in Sheep, pp. 262-268 [D. R. Lindsay and D. T. Pearce, editors]. Canberra: Australian Academy of Science and Australian Wool Corporation.

English, P. R. \& Wilkinson, V. (1982). Management of the sow and litter in late pregnancy and lactation in relation to piglet survival and growth. In Control of Pig Reproduction, pp. 479-506 [D. J. A. Cole and G. R. Foxcroft, editors]. London: Butterworths.

Faichney, G. J. \& White, G. A. (1987). Effect of maternal nutritional status on fetal and placental growth and on fetal urea synthesis in sheep. Australian Journal of Biological Sciences $40,365 \cdots 377$.

Faichney, G. J. \& White, G. A. (1988). Partition of organic matter, fibre and protein digestion in ewes fed at a constant rate throughout gestation. Australian Journal of Agricultural Research 39, 493-504

Ferguson, J. D. \& Chalupa, W. (1989). Impact of protein nutrition on reproduction in dairy cows. Journal of Dairy Science 72, 746-766. 
Ferrell, C. L. (1982). Effects of postweaning rate of gain on onset of puberty and productive performance of heifers of different breeds. Journal of Animal Science 55, 1272-1283.

Findlay, J. K. \& Clarke, I. J. (1987). Regulation of the secretion of FSH in domestic ruminants. Journal of Reproduction and Fertility, Suppl. 34, 27-37.

Fisher, G. \& MacPherson, A. (1986). Co deficiency in the pregnant ewe and lamb liability. Proceedings of the Sixth International Conference on Production Disease in Farm Animals, pp. 158162.

Flowers, B., Martin, M. J., Cantley, T. C. \& Day, B. N. (1989). The effect of pregnant mare serum gonadotropin on follicle stimulating hormone and estradiol secretion in the prepuberal gilt. Animal Reproduction Science 21, 93-100.

Foldager, J. \& Sejrsen, K. (1987). Mammary gland development and milk production in dairy cows in relation to feeding and hormone manipulation during rearing. In Research in Cattle Production, Danish Status and Perspectives. Frederiksberg: Landhusholdningsselskabets Forlag.

Forsyth, I. A. (1986). Variation among species in the endocrine control of mammary growth and function: the roles of prolactin, growth hormone, and placental lactogen. Journal of Dairy Science 69, 886-903.

Forsyth, I. A. (1989). Mammary development. Proceedings of the Nutrition Society 48, 17-22.

Foster, D. L., Ebling, F. J. P., Vannerson, L. A., Bucholtz, D. C., Wood, R. I., Micka, A. F., Suttie, J. M. \& Veenvliet, B. A. (1988). Modulation of gonadotrophin secretion during development by nutrition and growth. Proceedings of the Ilth International Congress on Animal Reproduction and Artificial Insemination 5, $101-108$. University College, Dublin.

Foster, D. L. \& Olster, D. H. (1985). Effect of restricted nutrition on puberty in the lamb: patterns of tonic luteinizing hormone (LH) secretion and competency of the LH surge system. Endocrinology 116, 375-381.

Foster, D. L., Yellon, S. M. \& Olster, D. H. (1985). Internal and external determinants of the timing of puberty in the female. Journal of Reproduction and Fertility 75, 327-344.

Gonzalez, J. S., Robinson, J. J. \& Fraser, C. (1985). The effect of physiological state on digestion in the ewe and its influence on the quantity of protein reaching the abomasum. Livestock Production Science 12, 59-68.

Goodall, E. A. \& McMurray, C. H. (1984). An integration of mathematical models for feeding and lactation with reproductive performance of the dairy cow. Animal Production 38, 341-349.

Gordon, K., Renfree, M. B., Short, R. V. \& Clarke, I. J. (1987). Hypothalamo-pituitary portal blood concentrations of $\beta$-endorphin during suckling in the ewe. Journal of Reproduction and Fertility 79, $397-408$.

Grandhi, R. R. (1988). Effects of nutritional fushing, supplemental fat and supplemental lysine from puberty to breeding and during early gestation on reproductive performance of gilts. Canadian Journal of Animal Science 68, 941-951.

Gunn, R. G. (1983). The influence of nutrition on the reproductive performance of ewes. In Sheep Production, pp 99-110 [W. Haresign, editor]. London: Butterworths.

Hamilton, W. \& Blaxter, K. L. (1980). Reproduction in farmed red deer. 1. Hind and stag fertility. Journal of Agricultural Science 95, 261273.

Hamra, A. M. \& Bryant, M. J. (1982). The effects of level of feeding during rearing and early pregnancy upon reproduction in young female sheep. Animal Production 34, 41-48.

Hansen, P. J. (1985). Seasonal modulation of puberty and the postpartum anestrus in cattle: a review. Livestock Production Science 12, 309-327.

Harrison, L. M. \& Randel, R. D. (1986). Influence of insulin and energy intake on ovulation rate, luteinizing hormone and progesterone in beef heifers. Journal of Animal Science 63, 1228-1235.

Hayek, M. G., Mitchell, G. E., Harmon, R. J., Stahly, T. S., Cromwell, G. L., Tucker, R. E. \& Barker, K. B. (1989). Porcine immunoglobulin transfer after prepartum treatment with selenium or vitamin E. Journal of Animal Science 67, 1299-1306.

Henniawati \& Fletcher, I. C. (1986). Reproduction in Indonesian sheep and goats at two levels of nutrition. Animal Reproduction Science 12, 77-84.

Hetzel, B. S. \& Mano, M. T. (1989). A review of experimental studies of iodine deficiency during fetal development. Journal of Nutrition 119, 145-151.

Horst, R. L., Reinhardt, T. A. \& Goff, J. P. (1989). Vitamin D and calcium metabolism in ruminants. In Proceedings of the International Meeting on Recent Progress on Mineral Nutrition and Mineral Requirements in Ruminants, pp. 3 10. Kyoto: Showado Insatsu Co.

Hurley, W. L. \& Doane, R. M. (1989). Recent developments in the roles of vitamins and minerals in reproduction. Journal of Dairy Science 72, 784804.

Inskeep, E. K., Braden, T. D., Lewis, P. E., Garcia-Winder, M. \& Niswender, G. D. (1988). Receptors for luteinizing hormone and follicle-stimulating hormone in largest follicles of postpartum beef cows. Biology of Reproduction 38, 587-591.

Johnsson, I. D. (1988). The effect of prepubertal nutrition on lactation performance by dairy cows. In Nutrition and Lactation in the Dairy Cow, pp. 171-192 [P. C. Garnsworthy, editor]. London: Butterworths.

Johnsson, I. D. \& Hart, I. C. (1985). Pre-pubertal mammogenesis in the sheep. 1. The effects of level of nutrition on growth and mammary development in female lambs. Animal Production 41, 323-332.

Johnsson, I. D. \& Obst, J. M. (1984). The effects of level of nutrition before and after 8 months of age on subsequent milk and calf production of beef heifers over three lactations. Animal Production 38, 57-68. 
Johnston, L. T., Fogwell, R. L., Weldon, W. C., Ames, N. K., Ullrey, D. E. \& Miller, E. R. (1989). Relationship between body fat and postweaning interval to estrus in primiparous sows. Journal of Animal Science 67 , 943-950.

Jones, C. T. \& Rolph, T.P. (1985). Metabolism during fetal life: a functional assessment of metabolic development. Physiological Reviews 65, 357-430.

Kelly, R. W. (1984). Fertilization failure and embryonic wastage. In Reproduction in Sheep, pp. 127 *133 [D. R. Linsday and D. T. Pearce, editors]. Canberra: Australian Academy of Science and Australian Wool Corporation.

Kemp, B., den Hartog, L. A. \& Grooten, H. J. G. (1989). The effect of feeding level on semen quantity and quality of breeding boars. Animal Reproduction Science 20, 245-254.

Ketut Sutama, I. \& Edey, T. N. (1985). Reproductive development during winter and spring of Merino ram lambs grown at three different rates. Australian Journal of Agricultural Research 36, 461-467.

Kinder, J. E., Day, M. L. \& Kittok, R. J. (1987). Endocrine regulation of puberty in cows and ewes. Journal of Reproduction and Fertility, Suppl. 34, 167-186.

King, R. H. (1987). Nutritional anoestrus in young sows. Pig News and Information 8, $15-22$.

King, R. H. (1989a). Effect of live weight and body composition of gilts at 24 weeks of age on subsequent reproductive efficiency. Animal Production 49, 109-115.

King, R. H. $(1989 b)$. A note on the effects of nutrient intake during the later stages of rearing and early reproductive life on the subsequent reproductive efficiency of gilts. Animal Production 48, 241-244.

King, R. H. \& Dunkin, A. C. (1986a). The effect of nutrition on the reproductive performance of first-litter sows. 3. The response to graded increases in food intake during lactation. Animal Production 42, 119-125.

King, R. H. \& Dunkin, A. C. (1986b). The effect of nutrition on the reproductive performance of first-litter sows. 4. The relative effects of energy and protein intakes during lactation on the performance of sows and their piglets. Animal Production 43, 319-325.

King, R. H. \& Martin, G. B. (1989). Relationships between protein intake during lactation, LH levels and oestrous activity in first-litter sows. Animal Reproduction Science 19, 283-292.

Kirkwood, R. N., Baidoo, S. K., Aherne, F. X. \& Sather, A. P. (1987a). The influence of feeding level during lactation on the occurrence and endocrinology of the postweaning estrus in sows. Canadian Journal of Animal Science 67, 405-415.

Kirkwood, R. N., Cumming, D. C. \& Aherne, F. X. (1987b). Nutrition and puberty in the female. Proceedings of the Nutrition Society 46, 177-192.

Kirkwood, R. N., Mitaru, B. N., Gooneratne, A. D., Blair, R. \& Thacker, P. A. (1988a). The influence of dietary energy intake during successive lactations on sow prolificacy. Canadian Journal of Animal Science 68, 283-290.

Kirkwood, R. N. \& Thacker, P. A. (1988). Nutritional factors affecting embryo survival in pigs (results and speculation). Pig News and Information 9, 15-21.

Kirkwood, R. N., Thacker, P. A., Gooneratne, A. D., Guedo, B. L. \& Laarveld, B. (1988 b). The influence of exogenous growth hormone on ovulation rate in gilts. Canadian Journal of Animal Science 68, $1097-1103$.

Kirkwood, R. N., Thacker, P. A. \& Laarveld, B. (1989). The influence of exogenous growth hormone on ovulation rate in gilts fed diets with different energy and protein intakes. Canadian Journal of Animal Science 69, 265-268.

Kleemann, D. O., Walker, S. K., Walkley, J. R. W., Smith, D. H., Grimson, R. J., Stafford, J. E. \& Seamark, R. F. (1988). The effect of nutrition during mid and late pregnancy on lamb birthweight and survival in F + Booroola $\times$ S.A. Merino ewes. Proceedings of the Australian Society of Animal Production 17, 428.

Lamb, I. C. (1985). Factors affecting fertility in the lactating domestic rabbit. PhD Thesis, University of Aberdeen.

Lang, J. (1981). The nutrition of the commercial rabbit. Part 1. Physiology, digestibility and nutrient requirements. Nutrition Abstracts and Reviews B 51, 197-225.

Loudon, A. (1987). Nutritional effects on puberty and lactational infertility in mammals: some interspecies considerations. Proceedings of the Nutrition Society 46, 203-216.

Loveridge, N., Caple, I. W., Rodda, C., Martin, T. J. \& Care, A. D. (1988). Further evidence for a parathyroid hormone-related protein in fetal parathyroid glands of sheep. Quarterly Journal of Experimental Physiology 73, $781-784$.

McDonald, B. J., O'Rourke, P. K., Connell, J. A. \& Hoey, W. A. (1988). Prenatal growth and estimation of fetal age in the Australian feral goat. Australian Journal of Agricultural Research 39, 729-734.

Mckelvey, W. A. C. \& Robinson, J. J. (1986). Embryo survival and growth in the ewe-recent studies on the effects of nutrition and on novel techniques for the recovery and transfer of embryos. In Annual Report of Studies in Animal Nutrition and Allied Sciences, Rowett Research Institute 41, 9-25.

McKelvey, W. A. C. \& Robinson, J. J. (1988). The use of reciprocal embryo transfer to separate the effects of preand post-mating nutrition on embryo survival and growth of the ovine conceptus. In Proceedings of the 11th International Congress on Animal Reproduction and Artificial Insemination 2, Paper no. 176. University College, Dublin.

McMurray, C. H., Rice, D. A., McLoughlin, M. \& Blanchflower, W. J. (1985). Cobalt deficiency and the potentia! of using methylmalonic acid as a diagnostic and prognostic indicator. In Trace Elements in Man and Animals, pp. 603-608 [C. F. Mills, I. Bremner and J. K. Chesters, editors]. Slough: Commonwealth Agricultura! Bureaux. 
MacPherson, A., Kelly, E. F., Chalmers, J. S. \& Roberts, D. J. (1987). The effect of selenium deficiency on fertility in heifers. In Trace Substances in Environmental Health, vol. 21, pp. 551-555 [D. D. Hemphill, editor]. Columbia, MO: University of Missouri.

Martin, R. E. \& Crenshaw, T. D. (1989). Effect of postnatal nutritional status on subsequent growth and reproductive performance of gilts. Journal of Animal Science 67, 975-982.

Masters, D. G. \& Moir, R. J. (1983). Effect of zinc deficiency on the pregnant ewe and developing foetus. British Journal of Nutrition 49, 365-372.

Matte, J. J., Girard, C. L. \& Brisson, G. J. (1984). Folic acid and reproductive performances of sows. Journal of Animal Science 59, 1020-1025.

Mellor, D. J. (1987). Nutritional effects on the fetus and mammary gland during pregnancy. Proceedings of the Nutrition Society 46, 249-257.

Mellor, D. J., Flint, D. J., Vernon, R. G. \& Forsyth, I. A. (1987). Relationships between plasma hormone concentrations, udder development and the production of early mammary secretions in twin-bearing ewes on different planes of nutrition. Quarterly Journal of Experimental Physiology 72, 345-356.

Mellor, D. J. \& Murray, L. (1982). Effects on the rate of increase in fetal girth of refeeding ewes after short periods of severe undernutrition during late pregnancy. Research in Veterinary Science 32, 377-382.

Mirando, M. A., Harney, J. P., Beers, S., Pontzer, C. H., Torres, B. A., Johnson, H. M. \& Bazer, F. W. (1990). Onset of secretion of proteins with antiviral activity by pig conceptuses. Journal of Reproduction and Fertility 88, 197-203.

Monget, P., Monniaux, D. \& Durand, P. (1989). Localization, characterization, and quantification of insulin-like growth factor-1-binding sites in the ewe ovary. Endocrinology 125, 2486-2493.

Moore, R. W., Bass, J. J., Winn, G. W. \& Hockey, H.-U. P. (1985). Relationship between carcass composition and first oestrus in Romney ewe lambs. Journal of Reproduction and Ferility 74, 433-438.

Mullan, B. P., Close, W. H. \& Cole, D. J. A. (1989). Predicting nutrient responses of the lactating sow. In Recent Advances in Animal Nutrition, pp. 209-243 [W. Haresign and D. J. A. Cole, editors]. London: Butterworths.

Mullan, B. P. \& Williams, I. H. (1989). The effect of body reserves at farrowing on the reproductive performance of first-litter sows. Animal Production 48, 449-457.

Nett, T. M. (1987). Function of the hypothalamic--hypophysial axis during the post-partum period in ewes and cows. Journal of Reproduction and Fertility Suppl. 34, 201-213.

Ngongoni, N. T., Robinson, J. J., Aitken, R. P. \& Fraser, C. (1989). Efficiency of utilization during pregnancy and lactation in the ewe of the protein reaching the abomasum and truly digested in the small intestine. Animal Production 49, 249-265.

Noblet, J., Close, W. H., Heavens, R. P. \& Brown, D. (1985). Studies on the energy metabolism of the pregnant sow. 1. Uterus and mammary tissue development. British Journal of Nutrition 53, 251-265.

Nottle, M. B., Hynd, P. I., Seamark, R. F. \& Setchell, B. P. (1988). Increases in ovulation rate in lupin-fed ewes are initiated by increases in protein digested post-ruminally. Journal of Reproduction and Fertility 84, 563-566.

Oyedipe, E. O., Osori, D. I. K., Akerejola, O. \& Saror, D. (1982). Effect of level of nutrition on onset of puberty and conception rates of zebu heifers. Theriogenology 18, 525-539.

Padmanabhan, V., Ebling, F. J. P., Sonstein, J., Fenner, D. E., Kelch, R. P., Foster, D. L. \& Beitins, I. Z. (1989). Bioactive follicle-stimulating hormone release in nutritionally growth-retarded ovariectomized lambs: regulation by nutritional repletion. Endocrinology 125, 2517-2526.

Parr, R. A., Davis, I. F., Fairclough, R. J. \& Miles, M. A. (1987). Overfeeding during early pregnancy reduces peripheral progesterone concentration and pregnancy rate in sheep. Journal of Reproduction and Fertility 80 , 317-320.

Parr, R. A., Williams, A. H., Campbell, I. P., Witcombe, G. F. \& Roberts, A. M. (1986). Low nutrition of ewes in early pregnancy and the residual effect on the offspring. Journal of Agricultural Science 106, 81-87.

Partridge, G. G. (1989). Nutrition of farmed rabbits. Proceedings of the Nutrition Society 48, 93-101.

Peters, A. R. \& Perera, B. M. A. O. (1989). Pulsatile secretion of oestradiol-17 $\beta$ in post-partum dairy cows. Animal Production 49, 335-338.

Petitclerc, D., Chapin, L. T., Emery, R. S. \& Tucker, H. A. (1983). Body growth, growth hormone, prolactin and puberty response to photoperiod and plane of nutrition in Holstein heifers. Journal of Animal Science 57, 892-898.

Phillippo, M., Humphries, W. R., Atkinson, T., Henderson, G. D. \& Garthwaite, P. H. (1987). The effect of dietary molybdenum and iron on copper status, puberty, fertility and oestrous cycles in cattle. Journal of Agricultural Science 109, 321-336.

Prime, G. R., Varley, M. A. \& Symonds, H. W. (1988). The effect of food intake during lactation and early pregnancy on plasma progesterone concentrations and prolificacy in multiparous sows. Animal Production 46, 499.

Pruitt, R. J., Corah, L. R., Stevenson, J. S. \& Kiracofe, G. H. (1986). Effect of energy intake after weaning on the sexual development of beef bulls. 2 . Age at first mating, age at puberty, testosterone and scrotal circumference. Journal of Animal Science 63, 579-585.

Prunier, A., Bonneau, M. \& Etienne, M. (1987). Effects of age and liveweight on the sexual development of gilts and boars fed two planes of nutrition. Reproduction, Nutrition, Développement 27, 689-700. 
Quirke, J. F. \& Gosling, J. P. (1979). Pre-pubertal plasma luteinizing hormone concentrations and progesterone concentrations during the oestrous cycle and early pregnancy in Galway and Fingalway female lambs. Animal Production 28, 1-12.

Rekwot, P. I., Oyedipe, E. O., Akerejola, O. O., Kumi-Diaka, J. \& Umoh, J. E. (1987). The effect of protein intake on the onset of puberty in Bunaji and Friesian $\times$ Bunaji crossbred bulls in Nigeria. Theriogenology 28, 427-434.

Reynolds, L. P., Ferrell, C. L., Robertson, D. A. \& Ford, S. P. (1986). Metabolism of the gravid uterus, foetus and utero-placenta at several stages of gestation in cows. Journal of Agricultural Science 106, 437. 444.

Rhind, S. M., Leslie, I. D., Gunn, R. G. \& Doney, J. M. (1985). Plasma FSH, LH, prolactin and progesterone profiles of Cheviot ewes with different levels of intake before and after mating, and associated effects on reproductive performance. Animal Reproduction Science 8, 301. 313.

Rhind, S. M., Leslie, I. D., Gunn, R. G. \& Doney, J. M. (1986). Effects of high levels of body condition and food intake on plasma follicle stimulating hormone, luteinizing hormone, prolactin and progesterone profiles around mating in Greyface ewes. Animal Production 43, $101-107$.

Rhind, S. M., Martin, G. B., McMillen, S., Tsonis, C. G. \& McNeilly, A. S. (1989a). Effect of level of food intake of ewes on the secretion of LH and FSH and on the pituitary response to gonadotrophin-releasing hormone in ovariectomized ewes. Journal of Endocrinology 121, 325-330.

Rhind, S. M., McKelvey, W. A. C., McMillen, S., Gunn, R. G. \& Elston, D. A. (1989b). Effect of restricted food intake, before and/or after mating, on the reproductive performance of Greyface ewes. Animal Production 48, 149 - 155.

Rhind, S. M., McMillen, S., McKelvey, W. A. C., Rodriguez-Herrejon, F. F. \& McNeilly, A. S. (1989c). Effect of the body condition of ewes on the secretion of LH and FSH and the pituitary response to gonadotrophinreleasing hormone. Journal of Endocrinology 120, 497-502.

Rhind, S. M. \& McNeilly, A. S. (1986). Follicle populations, ovulation rates and plasma profiles of LH, FSH and prolactin in Scottish Blackface ewes in high and low levels of body condition. Animal Reproduction Science 10, 105-115.

Richards, M. W., Wettemann, R. P. \& Schoenemann, H. M. (1989). Nutritional anestrus in beef cows: body weight change, body condition, luteinizing hormone in serum and ovarian activity. Journal of Animal Science 67, $1520-1526$.

Ritar, A. J. \& Adams, N. R. (1988). Increased ovulation rate but not FSH or LH concentrations, in ewes supplemented with lupin grain. Proceedings of the Australian Society of Animal Production 17, 310-313.

Robinson, J. J. (1983). Nutrition of the pregnant ewe. In Sheep Production, pp. 111-113 [W. Haresign, editor]. London: Butterworths.

Robinson, J. J. (1985). Nutritional requirements of the pregnant ewe. In Genetics of Reproduction in Sheep, pp. 361-370 [R. B. Land and D. W. Robinson, editors]. London: Butterworths.

Robinson, J. J. (1986a). Nutrition and embryo loss in farm animals. In Embryonic Mortality in Farm Animals, pp. 235-248 [J. M. Sreenan and M. G. Diskin, editors]. Dordrecht : Martinus Nijhoff Publishers.

Robinson, J. J. (1986 b). Changes in body composition during pregnancy and lactation. Proceedings of the Nutrition Society 45, 71-80.

Robinson, J. J. \& Aitken, R. P. (1986). Effects of nutrition on prenatal growth and the implications for perinatal survival in lambs. In Factors Affecting the Survival of Newborn Lambs, pp. 177188 [G. Alexander, J. D. Barker and $J$. Slee, editors]. Luxembourg: Commission of the European Communities.

Robinson, J. J. \& McDonald, I. (1989). Ewe nutrition, foetal growth and development. In Reproduction, Growth and Nutrition in Sheep, pp. 57-77 [O. R. Dýrmundsson and S. Thorgeirsson, editors]. Reykjavik: Agricultural Research Institute and Agricultural Society of Iceland.

Robinson, J. J., McDonald, I., Brown, D. S. \& Fraser, C. (1985). Studies in reproduction in prolific ewes. 8. The concentrations and rates of accretion of amino acids in the foetuses. Journal of Agricultural Science 105, 21- 26.

Rodda, C. P., Kubota, M., Heath, J. A., Ebeling, P. R., Moseley, J. M., Care, A. D., Caple, I. W. \& Martin, T. J. (1988). Evidence for a novel parathyroid hormone-related protein in fetal lamb parathyroid glands and sheep placenta : comparisons with a similar protein implicated in humoral hypercalcaemia of malignancy. Journal of Endocrinology 117, 261. 271 .

Roy, J. H. B., Gillies, C. M., Perfitt, M. W. \& Stobo, I. J. F. (1980). Effect of season of the year and phase of the moon on puberty and on the occurrence of oestrus and conception in dairy heifers reared on high planes of nutrition. Animal Production 31, 13-26.

Russel, A. J. F., Foot, J. Z., White, I. R. \& Davies, G. J. (1981). The effect of weight at mating and of nutrition during mid-pregnancy on the birth weight of lambs from primiparous ewes. Journal of Agricultural Science 97 , $723-729$.

Rutter, L. M. \& Manns, J. G. (1987). Hypoglycemia alters pulsatile luteinizing hormone secretion in the postpartum beef cow. Journal of Animal Science 64, 479-488.

Rutter, L. M., Snopek, R. \& Manns, J. G. (1989). Serum concentrations of IGF-1 in postpartum beef cows. Journal of Animal Science 67, 2060-2066.

Sasser, R. G., Williams, R. J., Bull, R. C., Ruder, C. A. \& Falk, D. G. (1988). Postpartum reproductive performance in crude protein-restricted beef cows: return to estrus and conception. Journal of Animal Science 66, 3033-3039. 
Seerley, R. W. (1984). The use of fat in sow diets. In Fats in Animal Nutrition, pp. 333-352 [J. Wiseman, editor]. London: Butterworths.

Seerley, R. W. (1989). Survival and post weaning performance of pigs from sows fed fat during late gestation and lactation. Journal of Animal Science 67, 1889-1894

Shurson, G. C., Hogberg, M. G., DeFever, N., Radecki, S. V. \& Miller, E. R. (1986). Effects of adding fat to the sow lactation diet on lactation and rebreeding performance. Journal of Animal Science 62, 672-680.

Short, R. E. \& Adams, D. C. (1988). Nutritional and hormonal inter-relationships in beef cattle reproduction. Canadian Journal of Animal Science 68, 29-39.

Silva, J. E. \& Larsen, P. R. (1986). Hormonal regulation of iodothyronine 5 -deiodinase in rat brown adipose tissue. American Journal of Physiology 251, E639-E643.

Simmen, F. A., Simmen, R. C. M., Letcher, L. R., Tavakkol, A. \& Bazer, F. W. (1989). Tissue-specific and developmental expression of insulin-like growth factor- 1 in the pregnant and lactating pig. In Biotechnology in Growth Regulation, p. 251 [R. B. Heap, C. G. Prosser and G. E. Lamming, editors]. London: Butterworths.

Smith, J. F. (1985). Protein, energy and ovulation rate. In Genetics of Reproduction in Sheep, pp. $349-359$ [R. B. Land and D. W. Robinson, editors]. London: Butterworths.

Smith, J. F. (1988). Influence of nutrition on ovulation rate in the ewe. Australian Journal of Biological Sciences 41, 27-36.

Spelsberg, T. C., Rories, C., Rejman, J. J., Goldberger, A., Fink, K., Lau, C. K., Colvard, D. S. \& Wiseman, G. (1989). Steroid action on gene expression: possible roles of regulatory genes and nuclear acceptor sites. Biology of Reproduction 40, 54-69.

Steiner, R. A. (1987). Nutritional and metabolic factors in the regulation of reproductive hormone secretion in the primate. Proceedings of the Nutrition Society 46, 159-175.

Stone, B. A. (1987). Determinants of embryonic mortality in the pig. Pig News and Information 8, 279-284.

Surendra Singh \& Vadnere, S. V. (1987). Induction of oestrus by supplementation of deficient minerals in postpartum anoestrus crossbred cows. Indian Journal of Animal Reproduction 8, 4649.

Symonds, H. W. \& Prime, G. (1989). The influence of volume of food intake by gilts on blood flow in the portal vein and clearance of progesterone from plasma. Animal Production 48, 620-621.

Teleni, E., Rowe. J. B., Croker, K. P., Murray, P. J. \& King, W. R. (1989). Lupins and energy-yielding nutrients in ewes. 2. Responses in ovulation rate in ewes to increased availability of glucose, acetate and amino acids. Reproduction, Fertility and Development 1, 117125.

Thatcher, W. W., McMillan, K. L., Hansen, P. J. \& Drost, M. (1989). Concepts for regulation of corpus luteum function by the conceptus and ovarian follicles to improve fertility. Theriogenology 31, 149-164.

Thomas, D. L., Thomford, P. J., Crickman, J. G., Cobb, A. R. \& Driuk, P. J. (1987). Effects of plane of nutrition and phenobarbital during the pre-mating period on reproduction in ewes fed differentially during the summer and mated in the fall. Journal of Animal Science 64, 1144-1152.

Toplis, P., Ginesi, M. F. J. \& Wrathall, A. E. (1983). The influence of high food levels in early pregnancy on embryo survival in multiparous sows. Animal Production 37, 45-58.

Topps, J. H. (1977). The relationship between reproduction and undernutrition in beef cattle. World Review of Animal Production 13 (2), 43-49.

Topps, J. H., Islam, M. N., Broadbent, P. J. \& Paterson, G. F. M. (1989). Effect of pre-calving nutrition on the performance of twin bearing beef cows and their calves. Animal Production 48, 617.

Trayhurn, P. (1989). Brown adipose tissue and nutritional energies where are we now? Proceedings of the Nutrition Society 48, 165-175.

Umberger, S. H., Goode, L., Caruolo, E. V., Harvey, R. W., Britt, J. H. \& Linnerud, A. C. (1985). Effects of accelerated growth during rearing on reproduction and lactation in ewes lambing at 13 to 15 months of age. Theriogenology 23, 555-564.

Van Lunen, T. A. \& Aherne, F. X. (1987). Effect of long-term feed restriction on age at puberty of gilts. Canadian Journal of Animal Science 67, 797.801 .

Villa-Godoy, A., Hughes, T. L., Emery, R. S., Chapin, L. T. \& Fogwell, R. L. (1988). Association between energy balance and luteal function in lactating dairy cows. Journal of Dairy Science 71, 1063-1072.

Vincent, I. C., Williams, H. Ll. \& Hill, R. (1985). The influence of a low-nutrient intake after mating on gestation and perinatal survival of lambs. British Veterinary Journal 141, 611-617.

Waddad, S. A. \& Gaili, E. S. E. (1985). Effect of nutrition on sexual development of western Sudan Baggara bull calves. Acta Velerinaria, Beograd 35, $299 \cdot 304$.

Weston, R. H. (1988). Factors limiting the intake of feed by sheep. XI. The effect of pregnancy and early lactation on the digestion of a medium-quality roughage. Australian Journal of Agricultural Research 39, $659-669$.

Whittemore, C. T. (1989). Advances in nutrient allowances for optimum production in breeding sows. In Recent Advances in Animal Nutrition in Australia 1989, pp. 172-177 [D. J. Farrell, editor]. Armidale: University of New England.

Wigmore, P. M. C. \& Stickland, N. C. (1983). DNA, RNA and protein in skeletal muscle of large and small pig fetuses. Grow'th 47, 67-76.

Williams, A. H. (1984). Long term effects of nutrition of ewe lambs in the neonatal period. In Reproduction in Sheep, pp. 272-273 [D. R. Lindsay and D. T. Pearce, editors]. Canberra : Australian Academy of Science and Australian Wool Corporation. 
Williams, G. L. (1989). Modulation of luteal activity in postpartum beef cows through changes in dietary lipid. Journal of Animal Science 67, 785-793.

Wolfe, M. W., Stumpf, T. T., Roberson, M. S., Wolfe, P. L., Kittok, R. J. \& Kinder, J. E. (1989). Estradiol influences on pattern of gonadotropin secretion in bovine males during the period of changed responses to estradiol feedback in age-matched females. Biology of Reproduction 41, 626 634.

Wollny, C., Wassmuth, R., Meinecke-Tillman, S. \& Dzapo, V. (1986). Endocrine and enzyme activity and maternal effects in relation to lamb survival. In Factors Affecting the Survival of Newborn Lambs, pp. 63-77. [G. Alexander, J. D. Barker and J. Slee, editors]. Luxembourg: Commission of the European Communities.

Wright, I. A., Rhind, S. M., Russel, A. J. F., Whyte, T. K., McBean, A. J. \& McMillen, S. R. (1987). Effects of body condition, food intake and temporary calf separation on the duration of the post-partum anoestrous period and associated LH, FSH and prolactin concentrations in beef cows. Animal Production 45, 395-402.

Wright, I. A., Russel, A. J. F. \& Hunter, E. A. (1986). The use of body condition scoring to ration beef cows in late pregnancy. Animal Production 43, 391-396.

Xu. Z. Z., McDonald, M. F. \& McCutcheon, S. N. (1989). The effects of nutritionally-induced liveweight differences on follicular development, ovulation rate, oestrous activity and plasma follicle stimulating hormone levels in the ewe. Animal Reproduction Science 19, 67-78.

Yang, H., Eastham, P. R., Phillips, P. \& Whittemore, C. T. (1989). Reproductive performance, body weight and body condition of breeding sows with differing body fatness at parturition, differing nutrition during lactation and differing litter size. Animal Production 48, 181-201. 